\title{
KARAMAN MÜZESİ'NDE BULUNAN BİR GRUP MÜHÜR BASKISI
}

Ertekin M. DOKSANALTI

Suhal SAĞLAN

\author{
Anahtar Kelimeler: • Mühür Baskısı $\bullet$ Doliche $\bullet$ Dülük $\bullet$ Zeus Dolichenus $\bullet$ Deksiosis \\ Keywords: Seal Impression • Doliche • Dülük • Zeus Dolichenus • Dexiosis
}

\section{Özet:}

Uygarlığın ve devlet geleneğinin temel unsurlarından biri de ticari ve resmi belgelerin arşivlenmesidir. Arşivleme ile ilgili en önemli veriler günümüze ulaşan mühürler ya da mühür baskilarıdır.

1983 yılında, Adıyaman civarında bulunduğu söylenen 48 adet mühür baskısı, satın alma yoluyla Karaman Müzesi Koleksiyonuna kazandırılmıştır. Makalemizde, resmi ve özel mühür baskılarından oluşan bu grubun karakteristik özellikleri ve ikonografileri incelenecektir. Ayrıca yayınlanmıs ya da yayınlanmayı bekleyen ve aynı bölgeden geldikleri ifade edilen diğer mühür baskılarıyla olan benzerlikleri de belirlenmeye çalışılarak, bu bölgedeki bilinen arşiv buluntuları ile karşılaştırmalar yapılıp, Karaman Müzesi Mühür baskılarının ait oldukları arşiv tespit edilmeye çalışılacaktır.

\section{Abstract: A Group of seal impressions from Karaman Museum}

One of the basic elements of the civilization and the government traditions is to record the commercial and official documents. The most important data's of the archives are the seal and seal impressions which have managed to come to today.

In 1983, 48 seal impressions estimated that have been founded excavated in the region of Adiyaman have been gained for the Karaman Museum Collection by purchasing. In the article in question, the characteristic features and iconography of this group which was consist of official and private seal impressions will be examined. In addition, the similarities of these seal impressions with the other seal impressions coming from the same region which were either published or waiting for to be published will be defined and the comparison will be made with the other findings of the archives and the archive belong to the Karaman Museum seal impressions will be clarified. 
Uygarlı̆̆ın ve devlet geleneğinin temel unsurlarından biri de ticari ve resmi belgelerin arşivlenmesidir. İnsanlığın yerleşik hayata geçip, ticaret faaliyetlerinin ve aidiyetlik duygusunun gelişmesi ile evrakların ve malların mühürlemesi geleneği de başlamıştır. $\mathrm{Bu}$ durum aynı zamanda arşivlerin de oluşmasina neden olmuştur. Arşivleme ile ilgili en önemli veriler günümüze ulaşan mühürler ya da mühür baskılarıdir.

Özellikle Hellenistik Dönem arşivlerinde, resmi ve özel belgeler özenle korunmuştur. Bürokratik yapısı oldukça gelişkin olan bu dönemde ve devam eden süreçte devlet kontrolü altında, daha geniş resmi arşivler oluşturulmuştur $^{1}$. Roma Dönemi'nde, resmi arşivlerin yanı sıra, özel arşivler de günlük ve ticari yaşamın önemli bir parçası olmuştur. Mühür baskılarının ortaya çıkartıldığı bazı önemli merkezlerde, resmi arşiv binalarının yanında, özel konutlarda da mühür baskılarının bulunması bu durumun en önemli işaretidir ${ }^{2}$. Güvenli oldukları için bazı önemli belgelerin tapinaklarda da korunduğu, başka bir deyişle tapınak arşivlerinin de varlığı bilinmektedir' ${ }^{3}$.

Haritada bugüne kadar bulunmuş olan Hellenistik ve Roma Dönemi arşiv-

Plantzos 1999, 22.

2 Zeugma, Dionysos ve Poseidon evi: Önal 2006, 50; Nea Paphos, Dionysos evi: Nicolaou 1971; Delos: Boussac 1982; Karanis, Milne 1906; Tigris Seleukeia'sı: McDowell 1935, Invernizzi 1968.

3 Orchoi: Rostovtzeff 1932. lerinin yer aldığı kentler gösterilmiştir (Harita 1). Kentleri işaret eden rakamlar, mühür baskısı bulunan merkezleri göstermekle birlikte, sayıca en fazla mühür baskısı bulunan kentten daha az örnekle temsil edilen kentlere doğru s1ralanmıştır. Haritada arşivlerin coğrafi dağılımlarının eşit olmadığ açıkça görülmektedir. Antik Çağ'da, ticaretin, haberleşmenin, bir devlet düzeninin olduğu her yerde bu mühür baskılarının kullanılmış olduğu göz önünde bulundurulursa, bu dengesiz durum iki şekilde açıklanabilir; bulunan arşivler ya henüz yayınlanmadı ya da henüz keşfedilmedi.

\section{Karaman Müzesi’ndeki Mühür Baskilari $^{4}$}

1983 yilında, Adıyaman civarında bulunduğu söylenen 48 adet mühür baskıs1, satın alma yoluyla Karaman Müzesi Koleksiyonu'na kazandırılmıştır. Makalemizde, resmi ve özel mühür baskılarından oluşan bu grubun karakteristik özellikleri ve ikonografileri incelenecektir. Ayrıca yayınlanmış ya da yayınlanmayı bekleyen ve aynı bölgeden geldikleri ifade edilen diğer mühür baskilariyla olan benzerlikleri de belirlenmeye çalış1larak, bu bölgedeki bilinen arşiv buluntuları ile karşılaştırmalar

\footnotetext{
Karaman Arkeoloji Müzesi'nde yer alan arkeolojik eserler katalogu, yayın çalışması olarak Kültür ve Turizm Bakanlığı'nın izni ile tarafımızdan hazırlanmaktadır. Bu çalışma sırasında bize büyük bir sabırla yardımcı olan Karaman Müze Müdürü Sayın Nurettin Özkan ve müze personeline en içten teşekkürlerimizi sunarız.
} 
yapılıp, Karaman Müzesi mühür bask1larının ait oldukları arşiv tespit edilmeye çalısıllacaktır.

Son yıllarda yoğun şekilde, Adıyaman çevresinde yer alan bazı antik yerleşimlerde, arşivler ya da arşivlere ait mühür baskıları bulunmuştur. Bunlar arasında genellikle şehrin koruyucu tanrısı ya da imparator,-yönetici portreleri veya sembollerinin bazen yazitlarla $d a$ birlikte yer aldığı resmi mühür baskıları sıklıkla görülmektedir. Resmi mühür baskıları yanında, boyut olarak daha küçük ve daha gösterişsiz, ancak kendine özgü nitelikler gösteren özel mühür baskıları da bu arşivlerden gelen malzeme arasındadır.

Bölgede şimdiye kadar tespit edilmiş en zengin arşiv, 100 binin üzerindeki mühür baskısıyla, Zeugma antik kentinin arşividir. Zeugma'nın $50 \mathrm{~km}$. batısinda yer alan Doliche antik kentinin arşivi büyük ölçüde kaçakçılar tarafından yağmalanmıştır. Yurt içi ve dışında pazarlanan Doliche mühür baskılarının müze ve özel koleksiyonlarda yer alan bir kısmı, çeşitli araştırmacılar tarafından yayınlanmıştır6. Doliche mühür baskılarından 750 tanesi satın alma yoluyla Gaziantep Müzesi'ne kazandırılmış, ancak henüz yayınlanmamıştır.

Önal 2006. Bölgedeki bilinen en zengin arşiv olan Zeugma antik kenti arşivinin bir kısmı M. Önal tarafından doktora tezi olarak çalışılmıştır.

6 Ronzevalle 1940; Maaskant-Kleibrink 1971; Klose 1984; Seyrig 1985; Weiss 1992; Weiss 2000; Konuk - Arslan 2000.
Bölgede arşiv veren bir diğer merkez, Nikopolis antik kentidir?

M.S. 253 ve 256 yıllarındaki I. Şapur yönetimindeki Sasani istilası, Ovalık Kilikya ve Kommagene'yi de kapsayan Kuzey Suriye şehirlerinin yağmalanarak, yakılıp yıkılmasıyla sonuçlanmıştır. Bölgede özellikle Nikopolis, Kyrrhos, Doliche, Zeugma ve Samosata kentleri ve çevresi bu yıkıma sahne olmuştur. $\mathrm{Bu}$ nedenle yukarıda zikredilen tarihler, söz konusu kentlerin arşivleri ve mühür baskılarının ait olduğu son yıllar için terminus post quem'dir. Aynı şekilde, bu bölgeden geldiği ifade edilen ve stilistik özellikleri ile kesinlikle Kommagene bölgesine bağlanan Karaman Müzesi koleksiyonundaki mühür baskıları için de bu tarih terminus post quem niteliği taşımaktadır. Olasılıkla bu istila sebebiyle yangin geçirmiş olan tabakada bulunmuş olduklarından, mühür baskıları, yanma neticesinde açı kahverengiden kiremit kırmızısı, hatta bazı örneklerde gri-siyah rengini almıştır.

Mühür baskılarının tümü, yaklaşı yassı formludur ve ön yüzlerinde figür bask1 yer almaktadır. Baskıların tümü pozitif olup, kabartma biçimindedir. Baskılar, oval ya da dairesel biçimde olup, düz veya konkavdır. Bir örnek d1şında üzerlerinde yazıt yoktur. Baskıların arka yüzlerinde ise bağlandıkları nesneye bağlı olarak papirüs, parşömen veya deri izleri mevcuttur. Killeri oldukça ince elenmiş ve yüksek kalitelidir. Belgenin bağlanmasında kullanılan ipin

Robert 1955; Klose 1984; Seyrig 1985. 
mühürde kalan izi tüm örnekler üzerinde açıkça görülmektedir. Mühür bask1ları üzerinde, kil henüz sslakken, kil çamurunun papirüs lifine veya ipe yat1r1lıp ikiye katlanması esnasında oluşan parmak izleri görülür.

Söz konusu 48 mühür baskısı, resmi ve özel mühür baskıları olmak üzere iki ana başlik altında incelenecektir. Bu ana başliklar altında, üzerlerinde yer alan figürlere göre alt başlıklara ayrılmıştır. Bunların içerisinde, ele alacağımız ilk grup, resmi mühür baskılarıdır.

\section{Resmi Mühür Baskıları (no: 1- 17)}

Koleksiyonumuz içerisinde yer alan resmi mühür baskıları, metal yüzüklerle yapılmıştır. Bunların mühür baskı alanı ve boyutu açısından diğer örneklere nazaran daha büyük ölçülerde olduğu açıkça görülmektedir. Bilindiği üzere resmi mühürler ile özel mühürleri birbirinden ayıran en önemli unsurlardan biri, resmi mühürlerin daha büyük ölçüde olmasidır'. Bu mühürler, kentin resmi makamlarının ya da bir tapinakrahip sınıfının resmi mühürleri olmalıdirlar.

\section{A. Mitolojik Karakterler (no: 1-9)}

Tykhe (no 1-4): Sağa dönük, bacaklarını çapraz yapmış vaziyette, kayalık bir tahtta oturan ve dizinden aşağ 1 sarkan sağ elinde buğday başağı demeti tu-

9 Seyrig 1985, 419; Plantzos 1999, 20- 21; Weiss 2000, 103. tan, giysili bir kadın figürü görülmektedir.

1- Müze Envanter No. 2475; düz oval bask1l; 16x14 mm; kil rengi 5YR 5/4; arka yüz deri veya parşömen izli.

2- Müze Envanter No. 2524; düz oval baskıl1; $17 \mathrm{x} 15 \mathrm{~mm}$; kil rengi $2.5 \mathrm{YR}$ 5/4; arka yüz papirüs izli; üst kısmı ve sağ taraf kırık ve eksik.

3- Müze Envanter No. 2569; düz oval bask1l; 16x19 mm; kil rengi 5YR 5/4; arka yüz deri veya parşömen izli; üst kısmı kırık.

4- Müze Envanter No. 2528; düz oval baskil1; 19x14 mm; kil rengi 5YR 5/4; arka yüz papirüs izli.

Yüksek, kayalık bir tahta oturan kadın figüründe Eutychides'in Antiokhia kenti için yaptığı Tykhe figürü kolaylıkla tanınmaktadır. Karaman Müzesi resmi mühür baskıları arasında en fazla sayıda temsil edilen figürlerden biri, Eutychides tipi Tykhe'nin gösterildiği mühür baskılarıdır.

Pausanias (Paus. P.H. 6.2.7), Lysippos'un öğrencilerinden biri olan Sikyon'lu Eutychides'in Antiokhia kenti için bir Tykhe yontusu yaptığını bildirir. Bizanslı kronikçi Malalas (Malalas Kron. 8.201), Antiochia'nın I. Seleukos Nikator tarafindan M.Ö. 300'de Silpios Dağ1 eteklerinde kuruluşunun hemen ardından bir Tykhe heykeli dikildiğinden ve figürün ayakları altındakinin Orontes olduğundan, Hiristiyanlık eğilimli de olsa bazı pasajlarında bahse- 
der $^{10}$. Sikkelere ek olarak, kandiller ve gemler üzerindeki ana tipi tekrarlanan, bacaklarını çapraz yaparak bir kaya üzerinde oturmuş kadın, çeşitli poz ve atribütlerle betimlenmiştir. Malalas, Antakya Tykhe'sinin bronzdan altın kaplama ikinci bir heykelinin Traianus Dönemi'nde inşa edilen tiyatronun bitimi onuruna yine Orontes üzerinde tahtta oturur vaziyette, dört sütunlu bir baldeken altına yerleştirilmiş olduğunu bildirir. Bir baldeken altında bulunan heykelin varlığını Roma İmparatorluk sikkeleri doğrular ${ }^{11}$.

Sikkeler üzerinde, elinde bereket boynuzuyla oturan Fortuna figüründen ayrilan ilk Tykhe figürü, Suriye'de M.Ö. 83-69 y1lları arasında yönetimde bulunmuş olan Ermeni Kralı I. Tigranes' in M.Ö. 77-73 yıllarına ait sikkelerinde görülür ${ }^{12}$. Daha sonra tekrar Roma İmparatorluk Dönemi'nde kullanılır ${ }^{13}$. Tigranes Dönemi'nde bastırılan sikkeler üzerindeki Tykhe figürünün elinde, Eutychides Tykhesi'nin elinde tuttuğu başak demeti yerine, Seleukoslara karşı kazandığı İpsos Savaşı'na ithafen, zaferi sembolize etmek üzere palmiye dalı yerleştirilmiştir $^{14}$. Tykhe'nin sembol olarak kullanıldığ1 Antakya sikkelerinde bu palmiye dall, Traianus Dönemi'nde yapılan ikinci heykele dek muhafaza edilmiştir;

10 Ridgway 1989, 233; Klose 1984, 64.

11 Ridgway 1989, 233.

12 Bedoukian 1978, no 7-11, 16-87, 91-98.

13 Wroth 1899, Lev. XX, no: 13.

14 Bedoukian 1978, no: 7-11, 16-87, 91-98; Wroth 1899, Lev. XXVII, no: 6.
Traianus'dan itibaren Tykhe, elinde başak demetiyle birlikte görülür ${ }^{15}$. M.Ö. 1 . yüzyılın sonundan itibaren, başka kentler de Eutychides Tykhesi'ni sikkeleri üzerinde göstermeye başlarlar. İlk olarak M.Ö. 43'te Tigris Seleuekia'si ve M.Ö. 1. yüzyılın sonunda Tarsus sikkeleri üzerinde bu figür görülmeye başlanır. Eutychides Tykhesi, M.S. 1. yüzy1lda Kilikya'da Augusta, Mallos ve Anazarbos, Kommagene'de Samosata, Suriye'de ise Apameia ve Kaisareia'ya dek yayllır ${ }^{16}$. M.S. 2. yüzyılın sonuyla birlikte Nikaia, Nikomedia (Bithynia), Kyzikos (Mysia), Midaion (Phrygia), Side, Sillion (Pamphylia), Tyana (Kapadokya), Germanika Kaiseria (Kommagene), Ake-Ptolemaios, Tyros (Fenike) ve Gerasa (Dekapolis) gibi şehirler tarafından da kullanılmıştır ${ }^{17}$. Başında şehir surlarını sembolize eden bir taçla taçlandırılmış kadın figürü, bugün bile bir şehri hatta bir milleti temsil etmekte ve sikkeler üzerinde yer almaktadir.

Eutychides Tykhesi'nin sikkelere ilaveten, çok sayıda mermer veya bronz kopyası bulunmuş, gem ve kandillerde bu tip yaygın olarak kullanılmışır. Gerek Zeugma ve Doliche'de gerekse bölgedeki diğer merkezlerde bulunan özellikle resmi mühür baskiları üzerinde Eutychides'in Tykhesi yaygin olarak kullanılmıştır. Buna bağlı olarak buluntu yeri belli olmayan Tykhe betimlemeli mühür baskılarının gerek tarihlendi-

15 Klose 1984, 65; Ridgway 1989, 235.

16 Klose 1984, 65, dn. 10.

17 Klose 1984, 65. 
rilmesi gerekse arşivinin belirlenmesi zordur.

Mühür baskıları üzerinde görülen Tykhe betimlemesinin tarihlendirmesi ile ilgili farklı görüşler ileri sürülmüştür. Karaman Müzesi Koleksiyonu'nda yer alan Tykhe betimlemeli mühür baskıları üzerinde yazıt bulunmamaktadır. Dolayisiyla tarihlendirilmeleri konusunda kesin bir yargıya ulaşmak kolay değildir.

Karaman mühür baskıları ile aynı stilde işlenmiş Tykhe betimlemeli mühür baskıları, Weiss ${ }^{18}$, Seyrig ${ }^{19}$, Balty ${ }^{20}$, M. Maaskant-Kleibrink ${ }^{21}$ ve Ronzevalle ${ }^{22}$ tarafından da yayınlanmıstır. Bunların çıkıs yeri olarak, arşivi kaçakçılar tarafından yağmalanmış, mühür baskıları özel müze ve koleksiyonlara dağılmış, Doliche antik kenti gösterilmiştir.

Eutychides'in Tykhesi bask1lı mühürler, Seyrig ve M. MaasakantKleibrink tarafından Hellenistik Dönem'e, Balty tarafından ise Erken İmparatorluk dönemine tarihlendirilmiştir. Seyrig'in, yayınında yer alan Tykhe betimli mühür baskısı üzerinde НПГ $(288)^{23}$, Klose'nin yayınlamıs olduğu yazttlı mühür baskısında ${ }^{24}$, benzer şekilde sağ altta 286 tarihi bulunmaktadır. Seyrig'e göre bu tarih Seleukoslar Dönemi'nin tarihi ile alakalıdır. Buna

18 Weiss 2000, 146b.

19 Seyrig 1985, 426, Lev. VI.

20 Balty 1981, 851, Lev. 676, no: 127.

${ }^{21}$ Maaskant-Kleibrink 1971.

22 Ronzevalle 1940.

23 Seyrig 1985, Lev. VI, no: 17.

24 Klose 1984, no: 7, Lev. 9, Res. 7.
Dönemi'nin tarihi ile alakalıdır. Buna göre mühürler M.Ö. 25-24 ve M.Ö. 2726 yillarina tarihlenir. Klose, tarihsiz Tykhe mühür baskılarını en erken Augustus Dönemi'ne ya da biraz daha geç bir döneme tarihlemiş, Hellenistik Dönem'e giden bir tarihlemeyi olası görmemiştir ${ }^{25}$.

Karaman Mühür baskıları için, benzer örnekler yardımıla Augustus Dönemi'ne ya da figürün elinde başak demeti tutması göz önüne alınarak Traianus Dönemi'ne ve sonrasına tarihlendirilmesi şeklinde iki farklı öneri sunulabilir.

Her ne kadar üzerindeki yazıttan dolayı Nikopolis kökenli olduğu ifade edilen, aynı tip mühür baskıları bilinse ve buna bağlı olarak benzer stildeki yazitsız örnekler Nikopolis'e atfedilse de ${ }^{26}$, bu grup mühür baskiları Doliche antik kenti ile alakalı olmalıdır. Doliche'de yapilan kazılarda ${ }^{27}$ ya da Gaziantep Müzesi'nin yaptığı kurtarma kazılarında bulunmuş veya satın alma yoluyla müze koleksiyonuna dâhil edilmiş mühür baskıları, Karaman mühür baskılarının orijini ile ilgili önemli veriler sağlamaktadır. Karaman örnekleri ile aynı mühürden basılmış olduklarını tespit ettiğimiz, Gaziantep Müzesi'ndeki henüz yayınlanmamıs mühür baskılarr ${ }^{28}$ ile

25 Klose 1985, 66.

26 Seyrig 1985, Lev. VI, no: 16-17; Klose 1984, 66, 67, no: $1-20$.

27 Blömer - Winter 2006, 194, Res. 13.

28 Gaziantep Müzesi koleksiyonunda yer alan söz konusu mühür baskıları, Doç. Dr. Mehmet Önal tarafından yayına hazırlanmaktadır. Bu çalışma sırasında bize karşılaştırma yapabilme olanağı sağ- 
Doliche kökenli olduğu bilinen bazı örnekler ${ }^{29}$, Karaman mühür baskılarının, Doliche arşivine ait olduğunu açıkça göstermektedir.

Zeus ve Hera (no: 5- 7): Solda, profilden, sola bakan, sakallı erkek başı, sağda profilden, sağa bakan, başı örtülü kadın başı olmak üzere yüz yüze betimlenmiş iki figür görülmektedir. 5 ve 6 numaralı mühür baskıları, kenarlarda küçük kırıklar olmasına rağmen tamdır. Ancak 7 numaralı mühür baskısında sağda yer alan erkek figürünün olduğu kısım kırılmıştır. Mühür baskılarının üçü de düz, oval yapıda olup, iki tanesinin arkasında papirüs, diğerinde deri izi görülmektedir.

5- Müze Envanter No. 2573; düz oval baskılı; 18x20 mm; kil rengi 5YR $5 / 3$, arka yüz papirüs izli.

6- Müze Envanter No. 2574; düz oval baskilı; $18 \times 24 \mathrm{~mm}$; kil rengi $2.5 \mathrm{YR}$ 5/6'dan 2.5YR 4/1'e değişiyor; arka yüz papirüs izli.

7- Müze Envanter No. 2526; düz oval baskılı; 17x13 mm.; kil rengi 2.5YR 5/3; arka yüz deri veya parşömen izli.

Ölçüleri ve karakteristik özellikleri ile resmi mühürler içerisinde değerlendirilen üç adet mühür baskısı üzerinde karşılıklı Zeus ve Hera'nın başlarının ikonografik özellikleri ile kolaylikla tanınabildiği mühür baskısı tespit edilmiştir.

ladığı için Gaziantep Müze Müdürlüğu’ne ve Sayın Doç. Dr. Mehmet Önal'a teşekkür ederiz.

29 Weiss 2000, 102.
Zeus'un başında strophion adi verilen bir başlık bulunmaktadır. Hera başı örtülü olarak betimlenmiştir. Benzer mühür baskıları Seyrig ${ }^{30}$, M. MaaskantKleibrink ${ }^{31}$ ve Weiss ${ }^{32}$ tarafından yayınlanmıştır. Bu büyük boyutlu resmi mühür baskılarında, Zeus ve Hera'nın başları yüksek kabartma şeklinde, güçlü bir Hellenistik etki göstermektedir. Karaman mühür baskılarında da aynı etkiyi görebilmek mümkündür. M. MaaskantKleibrink bu mühür baskılarının M.Ö. 1. yüzyıla ait olabileceğini ifade etmektedir $^{33}$. Stilistik özellikleri ile Karaman örnekleri geç Hellenistik ya da Augustus Dönemi'ne tarihlendirilebilinir.

Zeus ve Hera'nın birlikte betimlendiği bu mühür baskıları, Zeus Dolichenus kültüyle ilgili olup ${ }^{34}$, Doliche kentinin resmi mühür baskılarındandır ${ }^{35}$. Karaman mühür baskılar1nın bu bağlamda Doliche arşivi ile bağlantısı mümkün görülmektedir.

Zeus Dolichenus (no: 8): Başında tiara biçimli yüksek, konik bir başlık bulunan, çıplak erkek figürü ayakta ve sola dönük, sağ elini öne uzatmış olarak, profilden betimlenmiştir. Oval formlu baskının arkasında papirüs izi görülmektedir.

8- Müze Envanter No. 2523; düz oval bask1li; 17x11 mm; kil rengi 2.5YR

30 Seyrig 1985, Lev. 5, no: 5.

31 Maaskant-Kleibrink 1971.

32 Weiss 1992, 179-180.

33 Weiss 1992, 180.

34 Hörig - Schwertheim 1987, 20.

35 Weiss 1992, 180. 
5/4'ten 2.5YR 4/1'e değişiyor; arka yüz papirüs izli; ip deliği belirgin; sağ kısmı kırık.

Mühür baskısı kötü korunmuş olduğundan figürün detayları seçilememekle birlikte, bir deksiosis sahnesinin betimlenmiş olduğu açıkça anlaşılabilmektedir. Erkek figürü Zeus Dolichenus, ikonografisiyle kolaylikla tanınmaktadır ${ }^{36}$. Benzer örneklerden anlaşıldığ üzere, Zeus'un karşısında olmas1 gereken imparator figürü mühür baskı alanının dışında kalmışır

Zeus figürünün karşısında bulunmas1 gereken olası imparator figürünün korunamaması ve yazit bulunmaması Karaman mührünün tarihlendirilmesini zorlaştırmaktadır. Ancak bu bölge için, Zeus Dolichenus ile birlikte deksiosis sahnesi içindeki betimleme, özellikle Julius-Claudiuslar, Flaviuslar ve Severuslar döneminde yaygındır.

Doliche kökenli olduğu, söz konusu yayınlarda belirtilen deksiosis betimli mühür baskilar1 ${ }^{37}$, Zeus Dolichenus kültü ile ilişkilidir. Bu tip mühür baskılarının çoğu yazıtsız olmakla birlikte, Zeus Dolichenus ile Julius-Claudius sülalesinden bir imparator arasindaki deksiosis sahnesinin yer aldığg bir mühür baskısi ${ }^{38}$ üzerinde, mührün Doliche kentinin resmi mühür baskısı olduğunun kanıtı olan $\triangle \mathrm{O} \Lambda \mathrm{IXAI \Omega N}$ lejantı yer almaktadir.

36 Hörig - Schwertheim 1987, 20.

37 Weiss 1992, 175-178; Klose 1985, 66.

38 Seyrig 1985, 420, Res. 1; Weiss 2000, 101.
Beyrut eski eser pazarından satın alınıp, Klose tarafindan tanitilan ve Doliche kökenli olduğu ifade edilen, deksiosis sahneli üç mühür baskısından biri ile Karaman mühür baskısının, aynı mühürden basıldığı anlaşılmaktadır ${ }^{39}$.

Dioskurlar (no: 9): Detaylar belirgin olmamakla birlikte konik biçimli, oldukça yüksek başlıklarıyla, sakalsız, yüz yüze iki erkek başı seçilebilmektedir. Oval formlu baskının arkasında deri izi görülmektedir.

9- Müze Envanter No. 2571; düz oval bask1l; $16 \times 17 \mathrm{~mm}$; kil rengi 2.5YR 5/4; arka yüz deri izli; kenarlarda küçük kırıklar mevcut.

Dioskur'ların karşl1ıklı büstlerinin gösterildiği, buluntu grubumuz içerisinde tek örnekle temsil edilen mühür baskısı kötü korunmuştur. Buna karşın konik başlıkları ve genç yüzleri ile Dioskur'lar, mühür baskısı üzerinde açık ikonografileri ile tanınabilmektedir.

M. Maaskant- Kleibrink, benzer mühür baskısı tiplerini Geç Hellenistik Döneme tarihlendirmiştir ${ }^{40}$. Ancak Kastor Dolichenus'un Roma Dönemi'nde yaygın olması ve betimlemedeki Romalı özelliklerin ağır basması sebebiyle bu tür mühür baskıları Weiss tarafından M.S. 1. yüzyıla tarihlendirilmiştir ${ }^{41}$. Karaman mühür baskısı için ikinci öneri tarafımızdan destek görmektedir.

\footnotetext{
39 Klose 1984, Lev. 9, no: 23.

40 Weiss 1992, 182.

41 Weiss 1992, 182, 183.
} 
$\mathrm{Bu}$ bölgede Dioskur'lar, Zeus Dolichenos kültü için önemli bir rol oynar $^{42}$. Bu nedenle Dioskur'ların betimlendiği bu mühür baskısının, Doliche kentinin resmi mühürlerinden biri olduğunu söylemek mümkündür.

\section{7)}

B. İmparator Portreleri (no: 10-

Karaman Müzesi mühür baskıları içerisinde, resmi karakterleri gösteren portre mühürler, mitolojik konulu mühürlere nazaran daha az sayıda temsil edilmektedir. Ancak bu az sayıda örnek gerek tarihlendirme gerekse mühür baskılarının orijini ile ilgili önemli veriler sağlamaktadır.

Augustus (no: 10-15): Mühür baskısında, sağda başında defne çelengi bulunan, sağa bakan, profilden genç erkek başı; solda başında miğfer bulunan, sola bakan, profilden kadın başı bulunmaktadır. Kadın ve erkek başı karşılıklı olarak, yüz yüze betimlenmiştir. Kil renkleri kiremit kırmızısından kahverengikırmızıya değişir. Bazı örnekler üzerinde yanık izleri mevcuttur. Örneklerin hemen hemen tümünde farklı boyutlarda kırıklar mevcuttur. İki örnekte kadın başı (no: 11-12), bir örnekte (no: 13) erkek başı korunamamıştır. Arka yüzleri çoğunlukla papirüs izlidir.

10- Müze envanter No. 2575; düz oval baskıli; 16 x $11 \mathrm{~mm}$; kil rengi 2.5YR 5/4; kenarlar kırık; arka yüz papirüs izli.

42 Merlat 1960, 36-40, 88-98; Hörig - Schwertheim 1987, 20-23.
11- Müze Envanter No. 2464; düz oval bask1li; 19x11 m; kil rengi 5YR 5/6; arka yüz papirüs izli; sağ kısmın yarıya yakın bölümü kırık.

12- Müze Envanter No. 2568; düz oval bask1li; $18 \mathrm{x} 12 \mathrm{~mm}$; kil rengi $2.5 \mathrm{YR}$ 5/4'ten 2.5YR 4/3'e değişiyor; arka yüz papirüs izli.

13- Müze Envanter No. 2572; düz oval baskili; 16x15 mm; kil rengi 2.5YR 5/4; arka yüz papirüs izli; sol kısmı k1rik.

14- Müze Envanter No. 2527; düz oval bask11; 24x19 mm; kil rengi 2.5YR 5/4; arka yüz papirüs izli; üst ve alt kenarlarda küçük kırıklar mevcut.

15- Müze Envanter No. 2525; düz oval baskilı; 21 x $18 \mathrm{~mm}$; kil rengi 2.5YR 5/6'dan 2.5YR 3/1'e değişiyor; arka yüz deri veya parşömen izli; sağ kenarda kırıklar mevcut.

Karaman Müzesi mühür baskıları içerisinde en fazla sayıda temsil edilen mühür baskısı Augustus ve Dea Roma betimli mühür baskılarıdır. Başında defne çelenginden taç bulunan İmparator sağda, miğferli olarak betimlenmiş olan Dea Roma figürü sağda olmak üzere yüz yüze betimlenmişlerdir.

Sakalsız ve başında defne çelengiyle betimlenmiş olan erkek başının, fizyonomik özellikleri ve saç düzenlenişi, şüpheye yer birakmayacak şekilde Augustus'un tanınmasını sağlamakta$\mathrm{d}_{1} \mathrm{r}^{43}$. Profilden sola dönük işlenmiş Augustus'un gür saçları alın ve yüzü

43 Poulsen 1973, 63, 64. 
çevreler ve enseye doğru düşmüs yatay saç tutamları vardır. Bu özellikler nispeten daha iyi korunmuş olan 10-11 numaralı mühür baskılarında açıkça görülmektedir. Augustus'un bu portresi geniş alından ince çeneye doğru daralan Julius- Claudiuslar Dönemi stil özelliklerine sahip yüz yapısı, ideal genç yüz, çıkık elmacık kemikleri gibi kişisel yüz hatları ve saç düzenlenişi Augustus'un Prima Porta tipine işaret eder ${ }^{44}$.

Mühür baskısının diğer figürü olan miğferli kadın başı Tanrıça Roma ikonografisiyle tanımlanabilmektedir. Dea Roma figürü, Roma'nın ve Augustus'un dindarlığını yansıtması bakımından özellikle imparatorluğun ilk dönemlerinde çok popüler olmuştur ${ }^{45}$.

Augustus ve Dea Roma'nın karşıllklı betimlendiği, büyük boyutlu mühürler, Doliche kentinin resmi mühürleri arasındadırlar ve Doliche arşivine ait olan resmi mühür baskıları içerisinde en sık rastlanan örneklerdendir ${ }^{46}$. Karaman mühür baskıları da genel karakteristik özellikleri ile Doliche arşivine ait olmalidirlar.

Vespasianus (no: 16): Profilden, sola dönük, başında defne çelengi bulunan, ön kısımda saçları açılmış, sakalsız erkek başı görülmektedir.

16- Müze Envanter No. 2462; hafif konkav, oval bask11; $18 \times 11 \mathrm{~mm}$; kil rengi $2.5 Y R$ 6/6'dan 2.5YR 4/4'e deği-

44 Poulsen 1973, 63, 64, Lev. XLVII-XLIX, no: 32.

45 Seyrig 1985, 421.

46 Seyrig 1985, 420, Lev. V, no: 9. şiyor; arka yüz papirüs izli; sağda, başın arka kısmı kırık.

Mühür baskısındaki erkek başının başındaki çelenk ile yönetici konumu açıkça vurgulanmaktadır. Oldukça geniş ve güçlü alın yapısı, dökülmüş saçlar, çıkıntılı çene ve hafif kemerli burun yapisı ile diğer fizyonomik özellikler ${ }^{47}$, bu portrenin şüphe götürmez biçimde, M.S. 72'de Kommagene'yi imparatorluğa eyalet olarak ekleyen ${ }^{48}$ Vespasianus' göstermektir.

Doliche resmi mühürleri arasında yer alan Vespasianus baskilı örnekler ${ }^{49}$ ile Karaman mühür baskısı arasında stil açısından yakın benzerlikler bulunmaktadır.

Traianus (no: 17): Profilden, sola dönük, başında defne çelengi bulunan, sakalsız erkek başı görülmektedir. Başın arka kısmı ve saçlar iyi korunmus olmakla birlikte yüz oldukça siliktir. Mühür baskısında görülen siliklik, korunma durumu ile alakalı olmayıp, mühürleme işlemi sırasında baskının tam yapılmaması ya da mührün kendisindeki aşınma ile alakalı olduğu anlaşılmaktadir.

17- Müze Envanter No. 2587; düz oval baskili; 19 x $16 \mathrm{~mm}$; kil rengi 5YR 4/4; arka yüz papirüs izli.

Mühür baskısında görülen başın yüz kısmı büyük ölçüde silik de olsa sikke portrelerij ${ }^{50}$ ile yaptığımız karşılaştırma-

47 Poulsen 1974, 40-41, Lev. V-VI, no: 3.

48 Millar 1993, 80.

49 Seyrig 1985, Lev. 5, no: 10.

50 Matzke 1998, Lev. 158, no: 4635- 4640. 
lar sonucunda buradaki başın, Traianus'a ait olduğu açıkça görülmektedir. Arkada, başın merkezinden aşağ1ya taranan saç telleri, çıkık elmacık kemikleri ve burunun bitiminden başlayan ve verev olarak aşağ 1 indirilen yanaktaki kırışıklıktan İmparator Traianus'in fizyonomik özellikleri ${ }^{51}$ tespit edilebilmektedir.

Karaman mühür baskısı ile olasılıkla aynı mühürden basılmış, Doliche kökenli bir mühür baskısı Seyrig tarafından yayınlanmıştır ${ }^{52}$. Bu örnek, Karaman mühür baskısının Doliche arşivi ile alakalı olduğunu göstermektedir. Gerek boyut gerek betimleme özellikleri ile her iki mühür baskısının özdeş yapıda olduğu ancak Doliche örneğinin daha iyi korunduğu görülmektedir. Her iki baskısında da özellikle Traianus'ın yüz kısmının benzer şekilde aşınmış olması aynı mühürden çıktıkları düşüncesini güçlendirmektedir. Bunun yanında aşınmanın mührün kendisinde olduğu fikri de desteklenmektedir.

\section{II. Özel Mühür Baskıları (no: 18- 48)}

Karaman Müzesi mühür baskıları içerisinde, daha büyük boyutlu olan resmi mühür baskıları yanında, boyut olarak çok daha küçük olan, üzerlerinde çeşitli mitolojik karakterlerin, semboller ve hayvan betimlemelerinin, portrelerin yer aldığı, hem metal yüzüklerle hem de intaglio gemlerle basılan örnekler, özel

51 Poulsen 1974, 63-68, Lev. LVIII-LXI, no: 35.

52 Seyrig 1985, 420, Lev. 5, no: 11. mühür baskıları başlığı altında gruplandirılarak değerlendirilmiştir. Bu örnekler üzerindeki betimlemelere genel olarak baktığımızda, antik dönemin gliptik ve yontu sanatındaki ve ayrıca mühür baskıları üzerindeki sıkça rastlanan figürleri görürüz.

Bilinen arşivlerdeki mühür baskıları içerisinde, özel mühürlerin resmi mühürlere oranla çok daha fazla sayıda oldukları ve çeşitlilik arz ettikleri fark edi$\operatorname{lir}^{53} . \mathrm{Bu}$, şüphesiz resmi ve özel mühürlerin kullanım yerleri ve bu mühürleri taşıyan kişilerin sayısıyla doğru orantılı bir durumdur ${ }^{54}$.

\section{A. Mitolojik Karakterler (no:18-} 35) 30)

A.1. Tanrı ve Tanrıçalar (no: 18-

Bu gruptaki mühür baskılarının büyük kısmında kullanılan mühür yüzüğü taşlarının baskı yüzü ovaldir. Konveks biçimli yüzük taşlarının kil çamuruna basılmasıla, konkav baskı yüzeyi oluşmuştur. Genellikle tanrı ve tanrıça başlarının olduğu, daha geniş baskı alanlarıla, aynı zamanda dairevi ve düze yakın konkav yüzeyleriyle dikkat çeken örnekler (no: 25, 28, 32, 33), olasilıkla

53 Zeugma: Önal 2006, Lev. 14-25, 44-57, no: 1-220, 392-566; Tigris Seleukia's1: McDowell 1935, Lev. 16, no: 1-116, Invernizzi 1968, 69-124, Plantzos 1999, 31; Delos: Boussac 1982, 106, 427-446; Plantzos 1999, 32; Artaxata: Khachatrian 1996, 365-370.

54 Resmi ve özel mühürlerin kullanım alanlarıyla ilgili detaylı bilgi için bkz. Plantzos 1999, 18-22. 
kült organizasyonlarında kullanılan mühür baskılarıdır ${ }^{55}$.

$\mathrm{Bu}$ grupta yer alan mühür baskıları üzerinde Zeus, Zeus-Leda, Serapis, Helios ve Luna, Helios-Argeous, Fortuna, Tykhe, Nike, Hermes figürleri yer alır.

Zeus (no: 18): Sol elinde asa, sağ elinde şimşek demeti tutan Zeus figürü (no 18), profilden sağa dönüktür ve arkaliksız bir tahtta oturur vaziyettedir. Ayakları önünde bir kartal figürü yer almaktadır. Oval mühür baskısının alt kısmı kırıktır.

18- Müze Envanter No. 2576; konkav ve oval baskili; 12 x 13 mm; kil rengi 2.5 YR 4/4; arka yüz papirüs izli.

Zeus-Leda (no: 19): Mühür baskisı üzerinde solda Leda, sağda Leda'yı baştan çıkaran kuğu kıllğındaki Zeus betimlenmiştir. Figürler zemin çizgisi üzerinde yer alırlar.

19- Müze Envanter No. 2570; konkav ve oval baskill; 13 × $9 \mathrm{~mm}$; kil rengi 2.5YR 4/4; arka yüz papirüs izli.

Serapis (no: 20): Profilden sola dönük Serapis figürünün başında modius bulunmaktadır. Arkası papirüs izli mühür baskısının alt kısmı kırıktır.

20- Müze Envanter No. 2469; konkav ve oval bask1li; $10 \times 13 \mathrm{~mm}$; kil rengi 5YR 5/4'ten 5/6'ya değişiyor; arka yüz papirüs izli.

Helios-Luna (no: 21): Profilden sola dönük önde ışın tacıyla Helios, ar-

55 Klose 1985, 68. kada ve biraz öne çıkmış olarak Luna figürleri yer almaktadır.

21- Müze Envanter No. 2471; düz ve oval baskill; 10x8 mm.; kil rengi 5YR 4/2; arka yüz deri veya parşömen izli.

Helios-Argaeus (no 22): Mühür baskısı üzerinde Argaeus dağı ve zirvesinde gövde cepheden, ayakta, öne doğru uzattığ1 sağ elinde küre bulunan, sol eliyle de mızrağa dayanmış Helios figürü yer almaktadır. Zirvenin sağında yıl$\mathrm{d} \mathrm{z}$, solunda ay motifleri işlenmiştir.

22- Müze Envanter No. 2478; düz ve oval baskili; $13 \times 10 \mathrm{~mm}$.; kil rengi 5YR 5/4'ten 5YR 3/2'ye değişiyor; arka yüz deri veya parşömen izli.

Fortuna (no 23-24): 23 numaralı mühür baskısı üzerinde Fortuna figürü ayakta, sağa dönük olarak, 24 numaral $1^{56}$ mühür baskısı üzerinde ise kucağında bebekle oturur biçimde ve cepheden işlenmiştir. İkinci örnek fazlasıyla tahrip olduğundan figürün detayları belirgin değildir.

23- Müze Envanter No. 2480; konkav ve oval baskili; $10 \times 11 \mathrm{~mm}$; kil rengi 5YR 5/4; arka yüz deri veya parşömen izli.

24- Müze Envanter No. 2578; hafif konkav ve dairevi bask1li; $14 \times 16 \mathrm{~mm}$; kil rengi 2.5YR 5/6'dan 2.5YR 4/1'e değişiyor; arka yüz deri veya parşömen izli.

56 Benzer ya da aynı mühürden basılmış başka bir örnek Gaziantep Müzesi Koleksiyonu'nda yer almaktadır. Doliche'de bulunmuş olan mühür bask1s1, satın alma yoluyla Gaziantep Müzesi Koleksiyonu'na dahil edilmiştir. 
Tykhe (no: 25): Tykhe büstü giyimli olarak ve başında şehir suru tacıyla cepheden tasvir edilmiştir.

25- Müze Envanter No. 2467; hafif konkav ve dairevi baskılı; 14x16 mm.; kil rengi 5YR 6/4; arka yüz deri veya parşömen izli.

Nike (no: 26- 27): 26 numaralı mühür baskısı üzerinde sağa dönük ve ayakta betimlenmiş Nike figürü sol elinde zafer çelengi tutmaktadır. Aynı figür 27 numaralı mühür baskısı üzerinde de görülmekte olup burada sola dönük olarak işlenmiştir.

26- Müze Envanter No. 2530; konkav ve oval baskılı; 11x11 mm; kil rengi 2.5YR 5/3; arka yüz deri veya parşömen izli.

27- Müze Envanter No. 2577; konkav ve oval baskılı; 11x9 mm; kil rengi 2.5YR 4/3; arka yüz papirüs izli.

Hermes (no 28- 30): 28 ve 29 numaralı mühür baskıları üzerinde, sola dönük giysili büstüyle omzu üzerinde kerykeion taşıyan Hermes figürü yer alır. Her iki mühür baskısı da aşırı ısıya maruz kalmış olduklarından kil renkleri siyahtır. 30 numaralı mühür baskısı üzerinde yer alan Hermes figürü, gövde cepheden, baş sağa dönük, ayakta, sağ elinde para kesesi, sol elinde kerykeion tutar şekilde işlenmiştir.

28- Müze Envanter No. 2470; düz ve oval baskili; $13 \times 13 \mathrm{~mm}$; kil rengi 7.5YR 2,5/1; arka yüz papirüs izli.

29- Müze Envanter No. 2472; hafif konkav ve oval bask111; 10x8 mm; kil rengi 5YR 4/2'den 5YR 6/4'e değişiyor; arka yüz papirüs izli.

30- Müze Envanter No. 2481; konkav ve oval baskili; $11 \times 9 \mathrm{~mm}$; kil rengi 2.5YR 5/4'ten 5YR 5/4'e değişiyor; arka yüz deri veya parşömen izli.

Tanrı ve tanrıça betimlemeli özel mühür baskıları, Geç Hellenistik Dönem'den, buluntularımız için üst s1nır olan M.S. 253-256 yillarına kadar geniş bir zaman dilimi içerisine tarihlendirilirler. $\mathrm{Bu}$ grupta yer alan mühür baskıları üzerindeki tanrı ve tanrıça betimlemeleri, yukarıda da bahsedilmiş olduğu gibi, ait oldukları dönemin metal yüzükleri ve intaglio gemleri ve de sikkeleri üzerinde de sık sık karşımıza çıkan figürlerdir. Benzer mühür baskıları Zeugma mühür baskıları içerisinde de yer almaktadir ${ }^{57}$.

Yüzük taşları üzerindeki portreleri ve mitolojik karakterleri ustalıkla işleyen sanatçılar, aynı atölyelerde sikke kalıpları da hazırlamış olmalıdırlar.

Zirvesindeki Helios figüründen dolayı bu grup içerisinde değerlendirmeyi uygun bulduğumuz Argeaus (Erciyes) Dağ1 betimli mühür baskısı (no 22), Kappadokia Caesaraea sikkeleri üzerinde karşımıza çıkan en karakteristik motiftir $^{58}$. Bu düzenlemeye, geç Hellenistik Dönem'den itibaren Roma Dönemi boyunca basilan Caesarea sikkeleri üzerinde sık rastlanır ${ }^{59}$. Karaman Müzesi Koleksiyonu'nda yer alan mühür baskıları

\footnotetext{
57 Önal 2006, Lev. 14-18.

58 Bland 1996, Lev. 31-42.

59 Matzke 1998, Lev.159, no: 4650-4670.
} 
içerisindeki bu tek örnek, şimdiye kadar yayınlanmış Doliche arşivine ait mühür baskıları içerisinde yeni bir tiptir. Kappadokia Caesaraea kökenli tek örnek olması açısından önemlidir. 36)

\section{A.2. Mitolojik Varlıklar (no: 31-}

Mühür baskılarımız içerisinde altı örnek üzerinde, Medusa (?) (no: 31), Satyr $(32,33,34)$, Abraxas (no: 35) ve Spes (no: 36) gibi mitolojik varlık tasvirleri yer almaktadır. Mitolojik varlıklar da, tanrı ve tanrıça tasvirleri gibi, mühür baskıları üzerinde en sık rastlanan betimlemelerdendir.

Medusa (?) (no: 31): Mühür baskis1 çok aşınmış olmakla birlikte, üzerinde cepheden işlenmiş ve Medusa başı olduğunu düşündüğümüz figür yer alır. Figürün etrafını bir yazıt çevrelemektedir. Yazıtın bir kısmı eksik olmakla birlikte

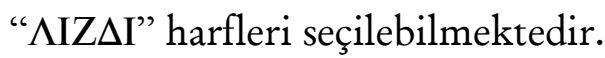

31- Müze Envanter No. 2532; düz ve dairevi baskil1; 9x8 mm; kil rengi $5 Y R \quad 4 / 3$; arka yüz deri veya parşömen izli.

Satyr (no 32- 34): 32 numaralı mühür baskısı üzerinde, sola dönük, bir dizi üzerine çökmüss vaziyette, önünde duran keçiyi sağmakta olan Satyr figürü işlenmiştir. Figürler zemin çizgisi üzerinde yer almaktadırlar. 33 ve 34 numaralı mühür baskıları üzerinde sola dönük Satyr başları bulunur. 33 numaralı örneğin kili, aşırı ısıdan dolayı siyahlaşmıştır.
32- Müze Envanter No. 2579; konkav ve oval baskıli; 11×12 mm; kil rengi 2.5YR 5/4; arka yüz papirüs izli.

33- Müze Envanter No. 2473; konkav ve oval baskili; $11 \mathrm{x} 9 \mathrm{~mm}$; kil rengi 5YR 2.5/1; arka yüz deri veya parşömen izli.

34- Müze Envanter No. 2468; düz baskil1; $12 \times 10 \mathrm{~mm}$; kil rengi 5YR 5/4'ten 5YR 4/2'ye değişiyor; arka yüz papirüs izli.

Abraxas (no: 35): Abraxas figürü gövde cepheden ve ayakta, sol elinde kırbaç, sağ elinde kalkan tutar şekilde betimlenmiş̧ir. Baş kısmı tahrip olmuştur. Kalkan tuttuğu sağ elin altında güneş motifi yer almaktadır. Abraxas figürünün etrafında yazıt bulunmaktadır. Ancak bu kısım da çok tahrip olduğundan harfleri ayırt edebilmek mümkün olmamaktadır.

35- Müze Envanter No. 2588; hafif konkav ve oval baskilı;11x9 mm.; kil rengi $10 \mathrm{R} 4 / 3$; arka yüz deri veya parşömen izli.

Spes (no: 36): Mühür baskısı üzerinde ayakta, sola dönük, profilden işlenmiş olan ve elinde çiçek tutan Spes figürü yer alır.

36- Müze Envanter No. 2531; konkav ve oval baskıli; $12 \times 11 \mathrm{~mm}$; kil rengi 2.5YR 5/4'ten 2.5YR 4/1'e değişiyor; arka yüz papirüs izli. 
B. Hayvan Betimlemeleri, Semboller ve Diğer Betimlemeler (no: $37-$ 41)

Özel mühürler içerisindeki dört adet mühür baskısı, üzerinde hayvan betimlemeleri ve sembollerin yer aldiğ örneklerdir. Bunlar üzerinde, boğa, ibis, üçayak, ay ve yıldız motifleri yer alır.

Boğa (no: 37): Sola dönük olarak işlenmiş ve zemin çizgisi üzerinde bulunan boğa figürünün üzerinde, kolları yukarı bakan hilal motifi yer almaktadir.

37- Müze Envanter No. 2477; düz ve oval baskilı; $12 \times 10 \mathrm{~mm}$; kil rengi 2.5YR 5/4'ten 5YR 6/4'e değişiyor; arka yüz papirüs izli.

İbis (no: 38): Mühür baskısı üzerinde 4/3'lük dönüşle işlenen ibis figürü yer almaktadir.

38- Müze Envanter No. 2482; düz ve oval bask1li; 9x10 mm; kil rengi 5YR 5/4'ten 5YR 3/2'ye değişiyor; arka yüz papirüs izli.

Üçayak (no: 39): Üçayak motifinin yer aldığı mühür baskısının alt kısmı k1riktır.

39- Müze Envanter No. 2476; hafif konkav ve oval baskılı; $13 \times 9 \mathrm{~mm}$; kil rengi 5YR 5/4; arka yüz deri veya parşömen izli.

Hilal-Yıldız (no: 40): Mühür bask1s1 üzerinde hilal motifi, her iki ucunda ve üst kısmında olmak üzere altı kollu yıldız motifleriyle üç yönden çevrelenmiştir. Mühür baskısının üst kısmı k1riktır.
40- Müze Envanter No. 2580; hafif konkav ve oval bask1li; $11 \times 9 \mathrm{~mm}$; kil rengi 2.5YR 5/4'ten 2.5YR 4/3'e değişiyor; arka yüz deri veya parşömen izli.

Quadriga (no: 41): Mühür baskıs1 üzerinde, dizginleri tutan figürün baskı alanı dışında kaldığı quadriga yer alır. Mühür baskisının üst ve alt kismında küçük kırıklar mevcuttur.

41- Müze Envanter No. 2479; düz ve dairevi bask1li; 10x12 mm; kil rengi; arka yüz deri veya parşömen izli.

Boğa (no 37), ibis (no 38), üçayak (no 39), hilal ve y1ldiz (no 40), Roma Dönemi mühür ve mühür baskıları üzerinde sıkça rastlanan figürlerdir. Zeugma arşivinde de örneklerimize benzer hayvan betimlemeleri ve sembollerin yer aldığı çok sayıda mühür baskısı bulunmuştur ${ }^{60}$.

Hellenistik ve Roma Dönemi gliptik sanatında hayvan betimlemeleri ve semboller geniş bir motif yelpazesine sahiptir. Bunların çoğunlukla dini ya da politik olan sembolik anlamları vardir. Ayrıca bu motifler çok geniş bir zaman diliminde kesintisiz olarak kullanıldıkları için tarihlendirilmeleri de son derece zordur.

\section{C. Özel Portreler (no: 42- 45)}

Karaman müzesi mühür baskıları içerisinde, Roma portre geleneğinde yapilmış olan imparator portreleriyle birlikte (no 10-17), dönemin resmi görevlileri veya şehrin ileri gelenlerine ait ol-

60 Önal 2006, Lev. 21, 23, 24, 55, no: 145, 178, 179 , 202, 203, 204, 542, 543. 
duklarını düşündüğümüz portreler de mevcuttur.

42- Müze Envanter No. 2529; hafif konkav ve oval baskili; $12 \times 10 \mathrm{~mm}$.; kil rengi 2.5YR 5/3; arka yüz papirüs izli.

42 numaralı mühür baskısinda, profilden sola dönük sakallı bir erkek portresi yer alır. Ense üzerinde sonlanan k1vircık, gür saçlar, tepeden alna doğru taranmış saç lüleleri, alnı çeviren saç bukleleri ve sakalın işlenişiyle Hadrianus portrelerini andırır. Zeugma arşiv kazılarında bulunmuş olan ve Hadrianus olarak isimlendirilen benzer bir örnek üzerinde, portrenin sol tarafında kollarını sekiz kollu yıldıza uzatan bir akrep figürü yer almaktadır ${ }^{61}$. Karaman mühür baskisinda akrep ve yıldız figürlerinin büyük bölümü baskı alanı dışında kalmıştır. Yıldızın yalnızca üç kolu ve akrep figürünün küçük bir kısmı kısmen seçilebilmektedir. Yıldızın üst kısmında, alın hizasinda olasilıkla yazıt görülmektedir. Ancak büyük bölümü baskı alanı dışında kaldığından okunamamaktadır.

43- Müze Envanter No. 2474; konkav ve oval baskili; $11 \times 8 \mathrm{~mm}$; kil rengi 7.5YR 2,5/1; arka yüz deri veya parşömen izli.

43 numaralı mühür baskısı üzerinde profilden sola dönük, defne çelenkli, giyimli, genç bir erkek portresi yer alır. Alnı ve yüzü çevreleyen gür saçlar, alna doğru taranmış ve alın üzerinde virgül biçimli saç lüleleri ve enseye doğru

61 Önal 2006, 145-146, Lev. 33, no: 277. düşmüs yatay saç tutamlarıyla JuliusClaudiuslar Dönemi portrelerine benzer. Badem biçimli gözler, hafif kemerli küçük burun, küçük ağız ve çeneye doğru incelen yüz yapısıyla Augustus, Tiberius ve Caligula'nın portre özelliklerini gösterir. Ancak hangi imparatoru ya da özel kişiyi betimlediği açık değildir.

44- Müze Envanter No. 2465; düz ve dairevi bask111; $12 \times 13 \mathrm{~mm}$; kil rengi 5YR 6/4'ten 5YR 5/4'e değişiyor; arka yüz deri veya parşömen izli.

44 numaralı örnekte yarım ay biçimli başlığ 1 ile sola dönük, profilden işlenmiş bir erkek portresi yer alır. Mühür baskısı kötü korunmuş olmakla birlikte, derinde verilmiş gözler, ince ve hafif kemerli burun, küçük ağı ve öne çıkık çene özellikleri seçilebilmektedir. Portrenin genel stil özellikleri JuliusClaudiuslar Dönemi'ni işaret etmektedir. Olasılıkla aynı mühürden basılmış olan ve Doliche kökenli olduğu ifade edilen mühür baskılarr ${ }^{62}$, M. MaaskantKleibrink ve Weiss tarafından yayınlanmış olup, Roma İmparatorluk Dönemi'ne tarihlendirilmişlerdir ${ }^{63}$.

45- Müze Envanter No. 2533; düz baskı1l; 10x9 mm.; kil rengi $2.5 \mathrm{YR}$ 4/3'ten 2.5YR 5/4'e değişiyor; arka yüz papirüs izli.

62 Doliche'de sürdürülen kurtarma kazılarında aynı ve benzer mühürlerden baskılar tespit edilmiştir. $\mathrm{Bu}$ konuda da dostane yardımları için Sayın M. Önal'a ve Gaziantep Müze Müdürlüğü'ne teşekkür ederiz.

63 Maaskant-Kleibrink 1971, 59, no: 117, 128; Weiss 1992, 184, no: 29. 
45 numaralı mühür baskısı üzerinde sağa dönük, profilden işlenmiş bir erkek figürü yer alır. Başın tepesinden yanlara ve alna düşmüs saçlarıyla bir portre olduğu anlaşılmakla birlikte, fazlasıyla tahrip olduğundan detaylar seçilememektedir.

\section{6- 48)}

D. Belirsiz Mühür Baskıları (no:

46- Müze Envanter No. 2466; düz baskılı; 13x11 mm.; kil rengi 5YR 4/2'den 5YR 5/4'e değişiyor; arka kısmı kirik.

47- Müze Envanter No. 2463; düz baskılı; 15x16 mm.; kil rengi 2.5YR 5/4; arka yüz papirüs izli.

48- Müze Envanter No. 2560; düz bask1lı; 12x11 mm.; kil rengi 2.5YR 3/3; arka yüz deri veya parşömen izli.

$46,47^{64}$ ve 48 numaralı mühür baskıları üzerinde profilden işlenmiş, sola dönük başlar yer almaktadır. Ancak fazlasıyla yıpranmış olduklarından portre mi yoksa mitolojik karakterlere mi ait oldukları konusunda kesin bir yargiya varmak mümkün değildir.

\section{Sonuç}

$\mathrm{Bu}$ araştırmayı oluşturan Karaman Arkeoloji Müzesi Koleksiyonu'nda yer alan 48 adet mühür baskısı üzerinde, mitolojik karakterler, günlük hayattan sahneler, semboller ve hayvan betimlemeleri ve tarihsel portrelerin yer aldığ

64 Benzer ya da aynı mühürden basılmış başka bir örnek Gaziantep Müzesi tarafından satın alınarak Müze Koleksiyonu'na dahil edilmiştir. resmi ve özel figürler olmak üzere 38 farklı tip saptanmıştır. Nispeten az sayıda olmasına karşın, bu küçük koleksiyon, betimlenen figürler açısından zengin bir çeşitlilik arz eder ve ait oldukları dönemin gliptik sanatı hakkında kaynak oluştururlar.

Özellikle Eutychides tipi Tykhe (no: 1- 4), Zeus Dolichenus ve Hera (no: 5- 7), Zeus-Dexiosis sahnesi (no 8), Dioskur'lar (no: 9), Augustus ve Dea Roma (no: 10- 15) figürlerinin yer aldığ1 resmi mühür baskıları, Karaman Müzesi'nde korunan bu mühür baskılarının kaynağ1 olarak Doliche kentini akla getirmektedir. Doliche kökenli olduğu ifade edilen mühür baskıları ile olan benzerlikleri ya da aynı mühürden basıldığ1 tespit edilen örnekler (no: 1-4, 8, 16-17, 24, 44, 47), Karaman mühür baskıları için açıkça Doliche kentini işaret etmektedir. 1940 y1lından günümüze, Doliche kökenli olduğu dile getirilen benzer mühür baskıları, küçük ya da büyük gruplar halinde yayınlanmış ve bu mühür baskıları üzerinde 150 civarında farklı tip tespit edilmiştir. Özellikle resmi mühür baskıları üzerindeki figürler birbirinin tekrarıdır ve büyük olasılıkla aynı mühürden veya mührün kopyalarından basılmış olmalıdırlar. Yayınlanmış olan bazı örnekler üzerindeki " $\triangle \mathrm{O} \Lambda \mathrm{IXAI \Omega N}$ " lejantı bunların kaynağının Doliche kenti olduğunun kesin kanıtıdır.

Kommagene'deki Doliche kenti, Gaziantep İli'nin $10 \mathrm{~km}$. kuzeyinde yer almaktadır ve Kommagene'nin güney 
sınırına oldukça yakındır. Doliche, Pompeius zamanında (M.Ö. 64) Roma idaresine girmiş ${ }^{65}$ Augustus Dönemi'nde de imparatorluğun Suriye Eyaleti'ne dâhil edilmiştir ${ }^{66}$. Doliche, biri Samosata'ya uzanan, biri Zeugma üzerinden Edessa'ya uzanan, biri Germanika ve diğeri Cyrrhus ve Antiokhia'ya uzanan ticari ve askeri Roma yollarının kavşak noktasında yer almıştır.

Yüz binin üzerinde mühür baskısıyla bilinen en zengin arşivlerden birine sahip olan Zeugma antik kenti, Doliche antik kentinin $50 \mathrm{~km}$ doğusunda yer almaktadır. Bu arşiv, Doliche arşivinin boyutları hakkında bize fikir vermektedir.

1940'l y yllardan yakın zamana kadar kaçak kazılara sahne olmuş ve dünyanın çeşitli yerlerindeki müze ve özel koleksiyonlara dağılmış olan Doliche antik kenti arşivine ait mühür baskıları, parça parça yayınlanmaya devam etmektedir. 1998 yılında Gaziantep Müzesi tarafindan Kebertepe Mevkii'nde yapılan bir yüzey araştırmasında kaçak kazıcıların elemiş olduğu toprağa karışmış mühür baskıları bulunmuştur. 2001 y1lindan beri Münster Üniversitesi'nden Engelbert Winter baskkanlığında, Jupiter Dolichenus Tapınağı'nın yer aldığı alanda arkeolojik kazılar devam etmektedir. Bu çalışmalarda da yine çeşitli mühür baskılarına rastlanmıştır. Bu kazilarda bulunan örneklerin ve de Gazi- antep Müzesi Koleksiyonu'ndaki geliş yeri kesin olarak Doliche olduğu bilinen mühür baskılarının, Karaman Müzesi'nde korunan örnekler ile benzer, hatta bazılarının aynı mühürden basılmış olması, bunların kesinlikle Doliche kökenli olduklarının bir başka tartışmasız kanitıdır.

Yrd. Doç. Dr. Ertekin M. DOKSANALTI

Selçuk Üniversitesi

Edebiyat Fakültesi

Arkeoloji Bölümü

Kampüs 42031 Konya

e-mail: ertekin96@selcuk.edu.tr

Arş. Gör. Suhal SAĞLAN

Selçuk Üniversitesi

Edebiyat Fakültesi

Arkeoloji Bölümü

Kampüs 42031 Konya

e-mail: suhalsaglan@gmail.com

\section{Harita ve Resim Listesi:}

Harita 1. Hellenistik ve Roma Dönemlerine Ait Mühür Baskıları Bulunan Antik Kentler

${ }_{65}$ Atlan 1970, 146-147.

${ }^{66}$ Millar 1993, 248. 


\section{KAYNAKÇA}

Atlan 1970

Bedoukian 1978

Balty 1981

Bland 1996

Blömer - Winter 2006

Boussac 1982

Hörig - Schwertheim 1987

Invernizzi 1968

Khachatrian 1996

Klose 1984

Konuk - Arslan 2000

Maaskant-Kleibrink 1971

McDowell 1935

Matzke 1998

Merlat 1960

Millar 1993

Milne 1906

Nicolaou 1971

Önal 2006

Plantzos 1999

Poulsen 1973

Poulsen 1974

Ridgway 1989

Robert 1955

Ronzevalle 1940

Rostovtzeff 1932
S. Atlan, Roma Taribinin Ana Hatlarn (1970).

P. Z. Bedoukian, Coinage of the Artaxiads of Armenia (1978).

J. Ch. Balty, “Antiocheia”, LIMC I/1-2, 1981, 840-851.

R. Bland, "The Bronze Coinage of Gordian III from Caesarea in Cappadocia”, Studies in Ancient Coinage from Turkey, 1996, 49- 95.

M. Blömer - E. Winter, "Der Dülük Baba Tepesi bei Doliche und das Heiligtum des Iupiter Dolichenus 2. Vorbericht (2004- 2005)", IstMitt 56, 2006, 185-205.

M. F. Boussac, “A propos de quelques sceaux Déliens" BCH 106, 1986, 427446.

M. Hörig - E. Schwertheim,Corpus Cultus Iovis Dolicheni, EPRO 160 (1987).

A. Invernizzi, "Bullae From Seleucia”, Mesopotamia 3/4, 1968, 69-124.

Z. Khachatrian, "Archives of Sealing Found at Artastat (Artaxata)", $B C H$ Sup. 29, 1996, 365-370.

D. O. A. Klose, "Nikopolis und Doliche”, JNG 34, 1984, 62-75.

K. Konuk - M. Arslan, Ancient gems and finger rings from Asia Minor, The Yüksel Erimtan Collection (2000).

M. Maaskant-Kleibrink, "Cachets de terre de Doliche(?)" BABesch 46, 1971, 23-63.

R. H. McDowell, Stamped and Inscribed Objects from Seleucia on the Tigris,. University of Michigan Studies. Humanistic Series XXXVI (1935).

M. Matzke, "Phrygien-Kappadokien Römische Provinzprägungen in Kleinasien ", SNG 6, 1998, Nr.4207-4713.

P. Merlat, Jupiter Dolichenus (1960).

F. Millar, The Roman Near East, 31 B.C. - A.D. 337 (1993).

J. G. Milne, "Clay Sealings From the Fayoum”, JHS 26, 1906, 32-45.

K. Nicolaou, "11.000 Seal Impressions in Cyprus", ILN 259, 1971, 51-53.

M. Önal, Zeugma Mübür Baskilarında Krallar, Imparatorlar, Imparatoriçeler, Filozoflar ve Semboller (Yayınlanmamıs Dok. Tezi-2006).

D. Plantzos, Hellenistic Engraved Gems (1999).

V. Poulsen, Les Portraits Romains I: Republique et Dynastie Julienne (1973).

V. Poulsen, Les Portraits Romains II: De Vespasien a la Basse-Antiquite (1974).

B. S. Ridgway, Hellenistic Sculpture I (1974).

L. Robert, "Cachet de Nikopolis", Hellenica 10, 1955, 293-294.

S. Ronzevalle. "Les monnaies et la dinastie de Abd Hadad et les cultes de Hierapolis, Babbyce”, MUSJ XXIII, 1940, 69-77.

M. Rostovtzeff, "Seleucid Babylonia: Bullae and Seals of Clay with Grek In- 
Sanders 1902

Seyrig 1985

Weiss 1992

Weiss 2000

Wroth 1899 scriptions", Yale Classical Studies 3, 1932, 47-48.

C. S. Sanders, "Jupiter Dolichenus", Journal of the American Oriental Society 23, 1902, 84-92.

H. Seyrig, "Cachets D'archives Publiques de Quelques Villes de La Syrie Romaine”, Scripta Varia, Melanges d'archeologie et d'histoire, 1985, 417-441.

P. Weiss, "Neue Tonsiegel von <Doliche >", Chiron 22, 1992, 171-193.

P. Weiss, “Tonsiegel aus Kommagene (Doliche)", J. Wagner (ed.), Gottkönige am Euphrat. Neue Ausgrabungen und Forschungen in Kommagene (2000) 101-103.

W. Wroth, British Museum. Catalogue of Greek Coins of Galatia, Cappadocia and Syria (1899). 


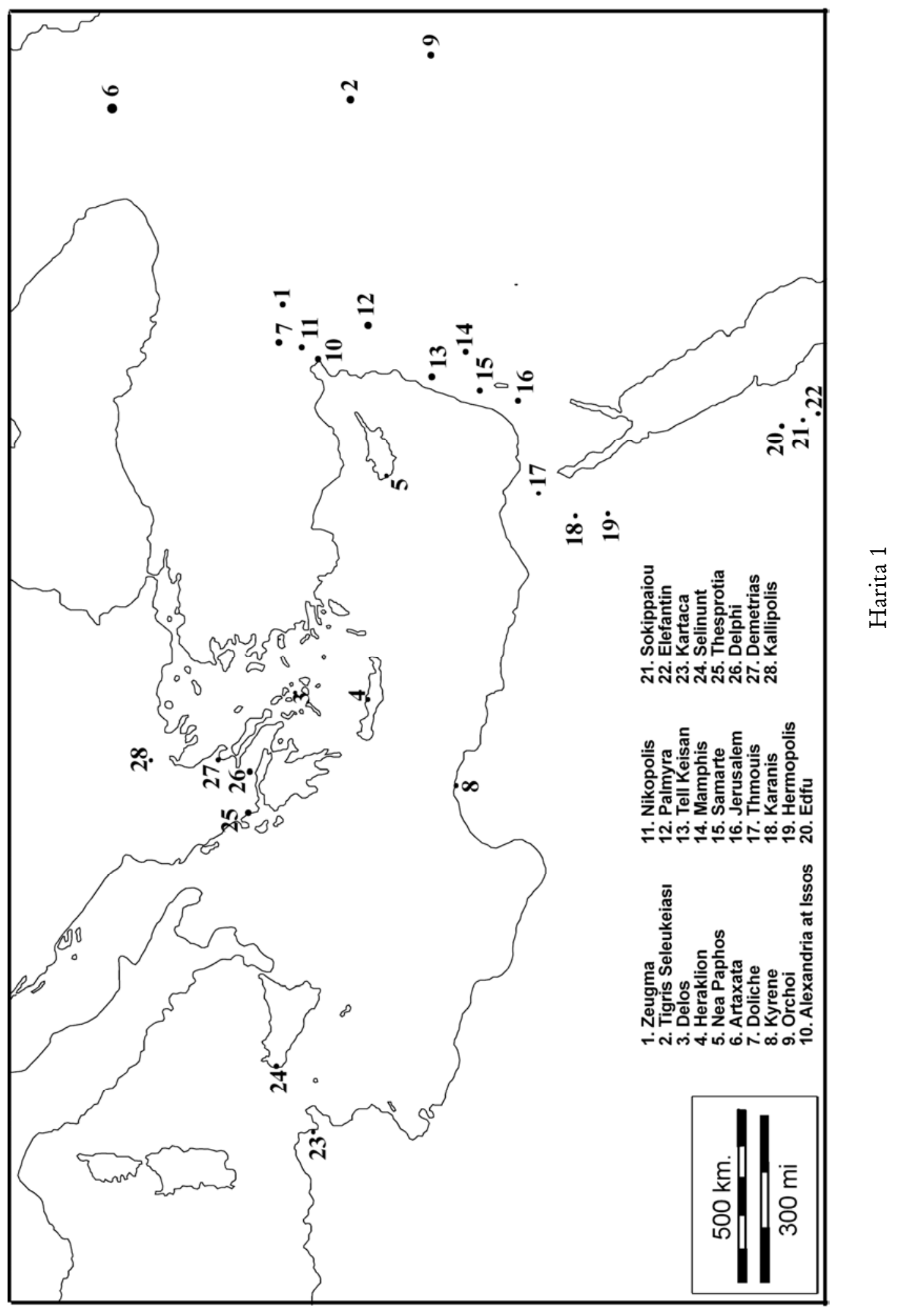


Karaman Müzesi’nde Bulunan Bir Grup Mühür Baskısı

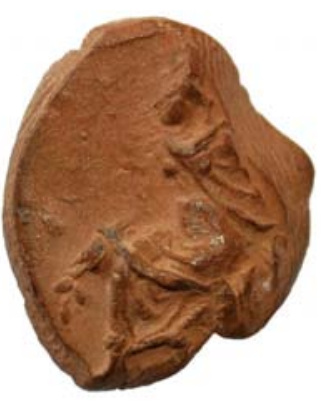

1

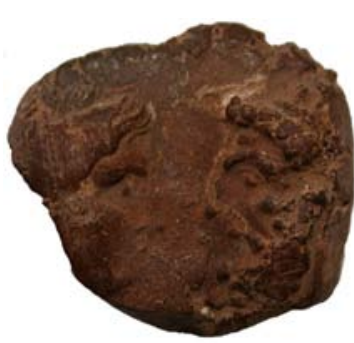

5

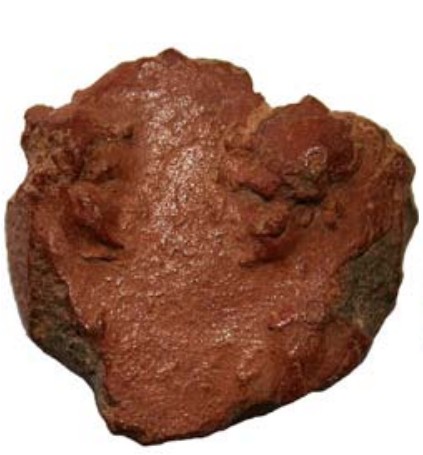

9

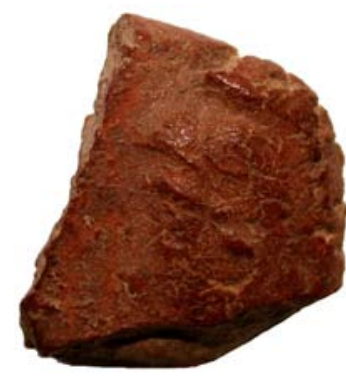

13

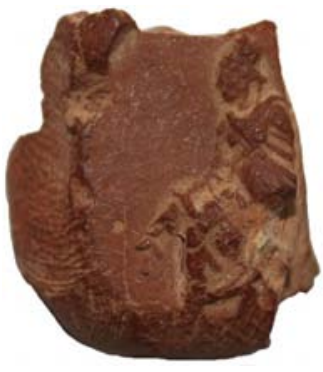

2

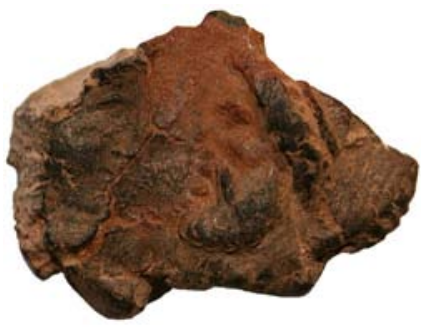

6

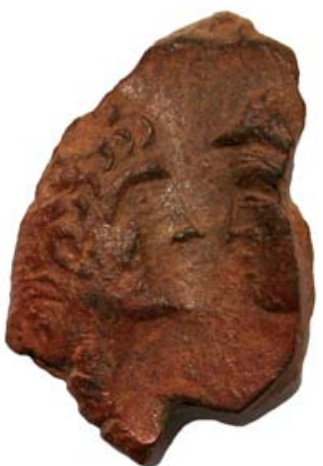

10

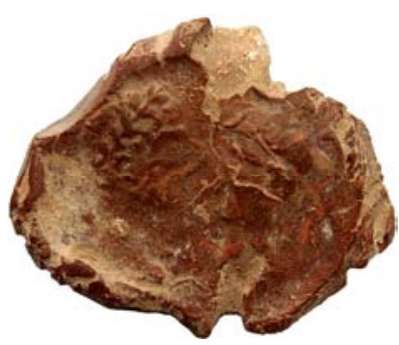

14

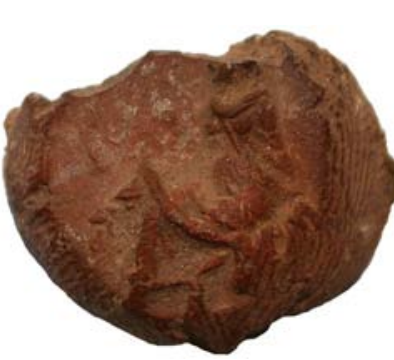

3

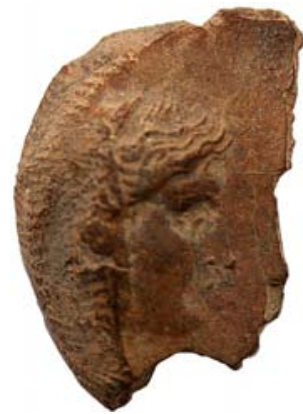

7

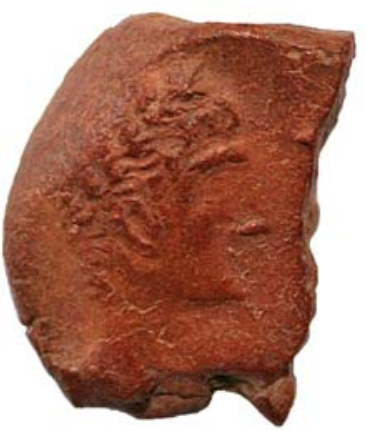

11

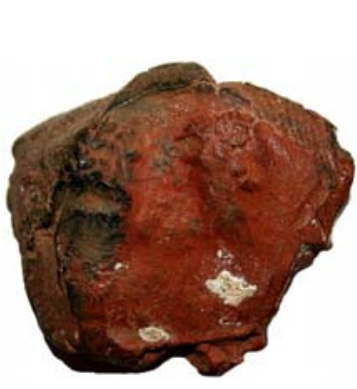

15
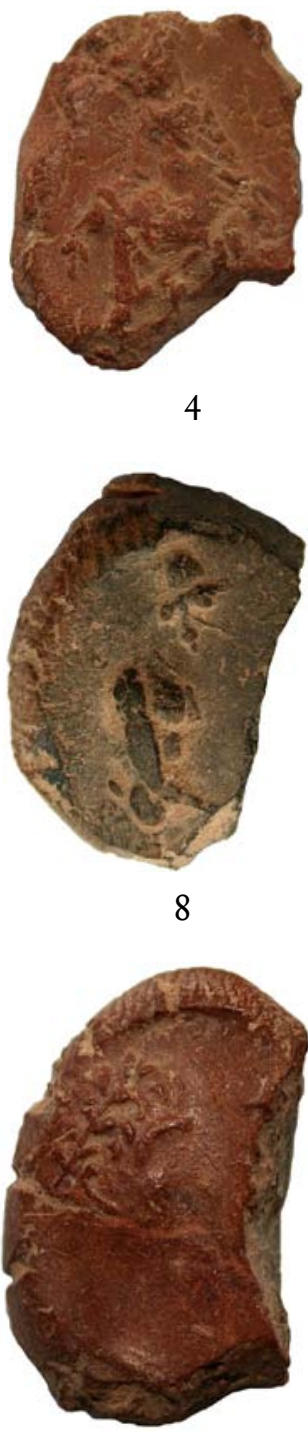

12

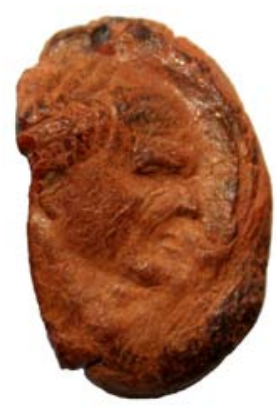

16 


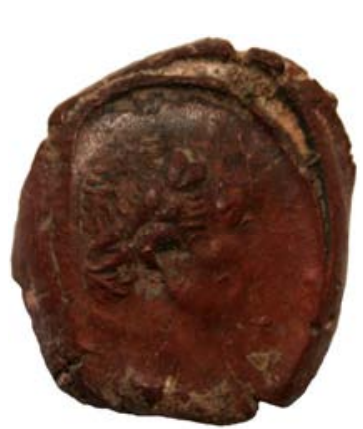

17

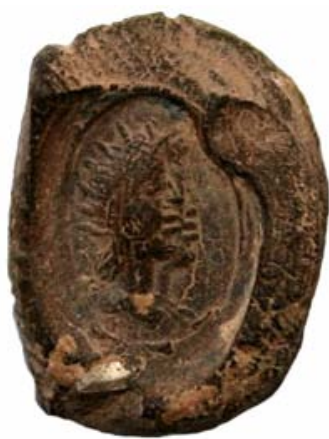

21

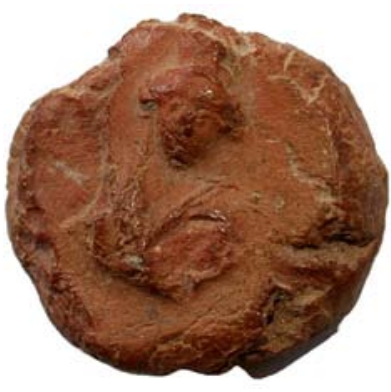

25

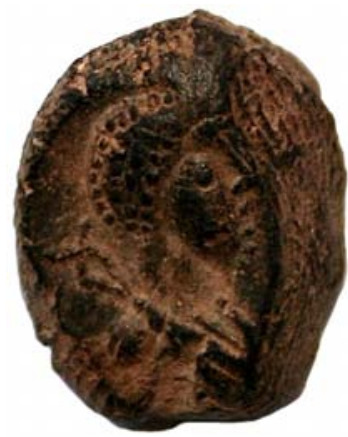

29

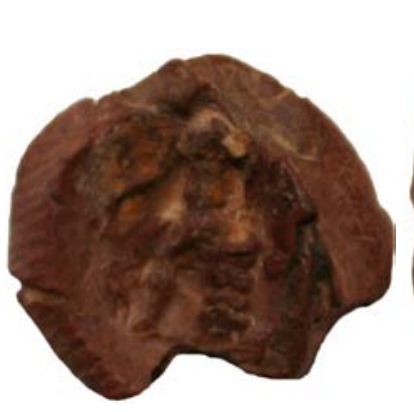

18

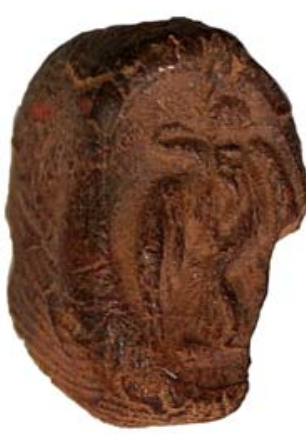

19

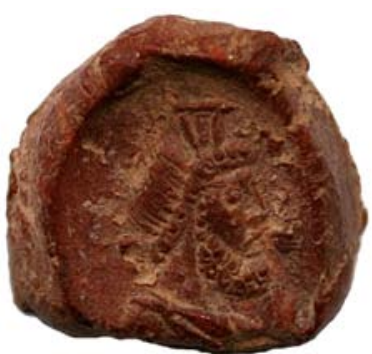

20

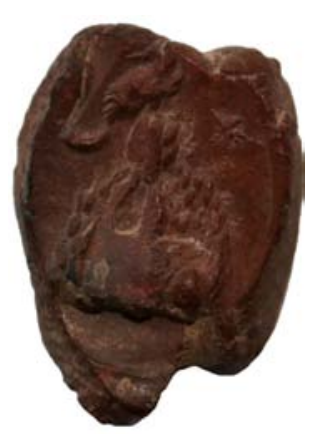

22

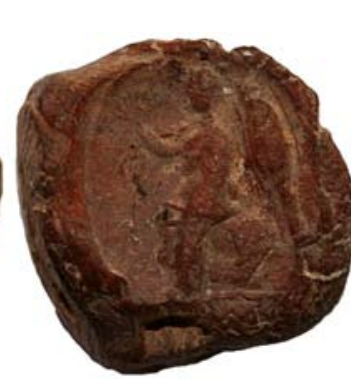

26

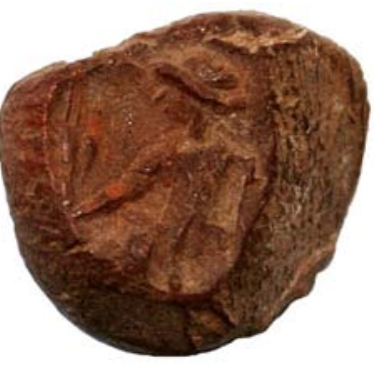

23

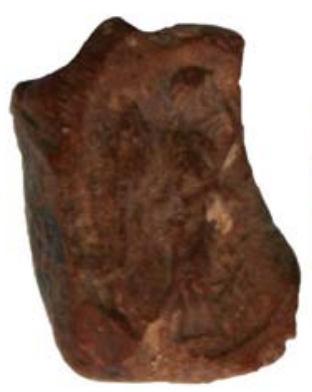

27

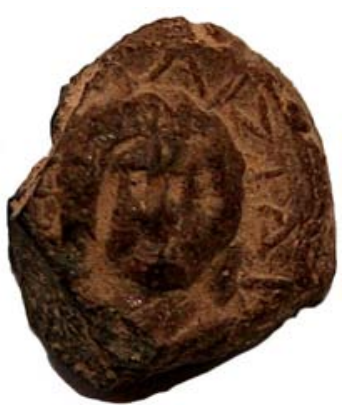

31

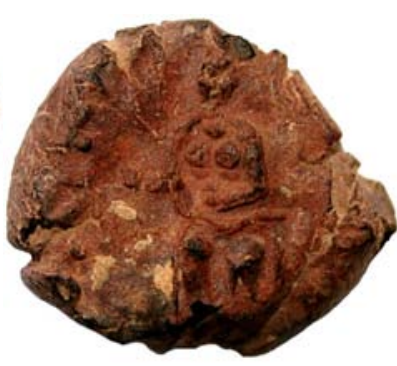

24

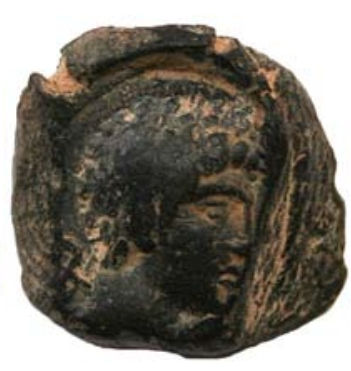

28

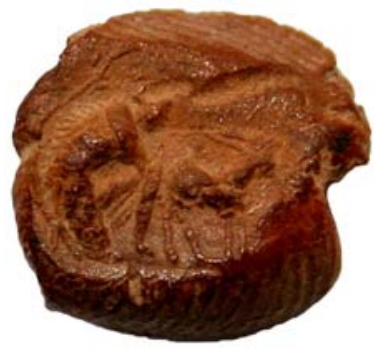

32 
Karaman Müzesi’nde Bulunan Bir Grup Mühür Baskısı

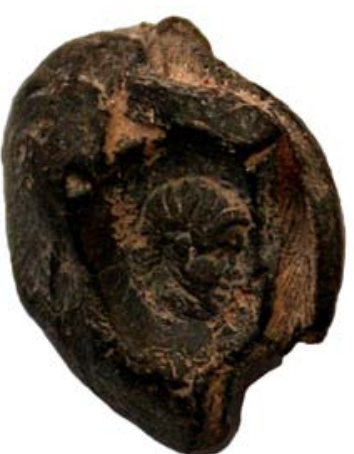

33

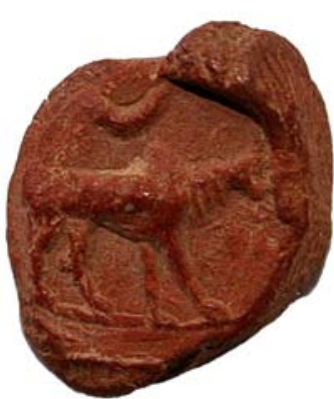

37

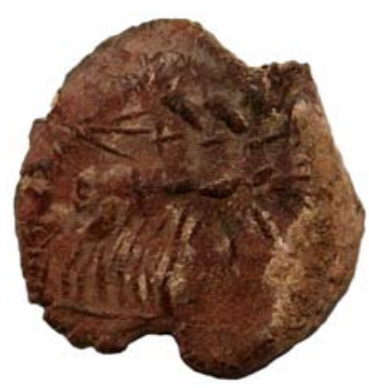

41

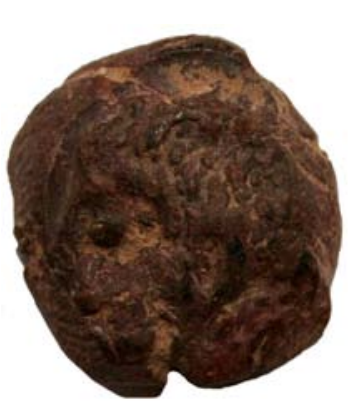

45

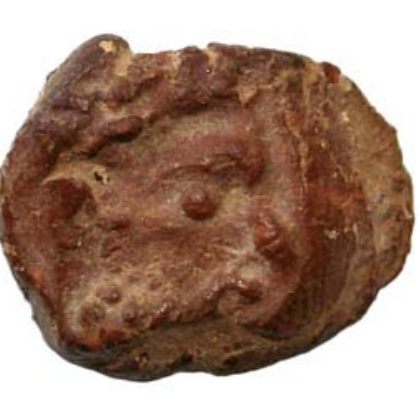

34

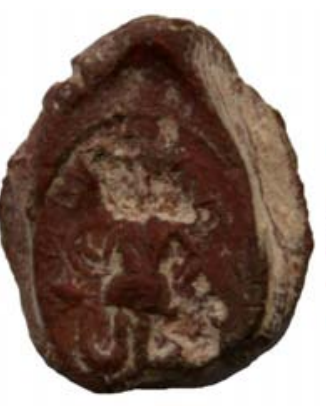

35

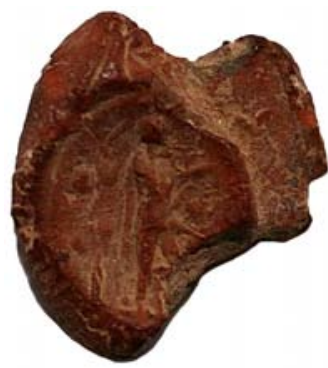

36

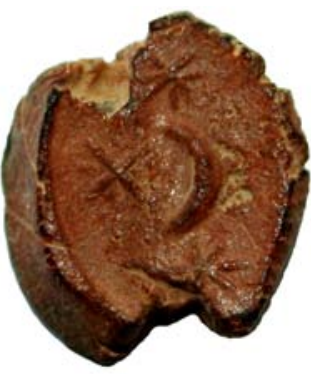

40

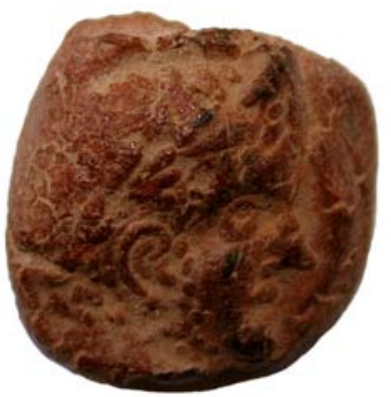

44

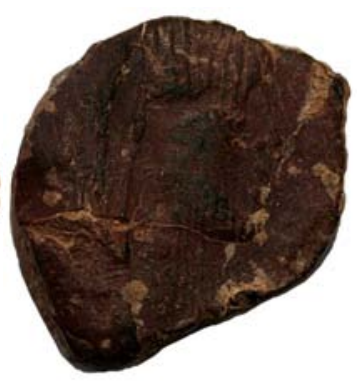

48 